\title{
Angiostrongylus costaricensis life cycle in the intermediate host Sarasinula marginata Semper, 1885 (Mollusca: Soleolifera)
}

Ciclo evolutivo do Angiostrongylus costaricensis no hospedeiro intermediário Sarasinula marginata Semper, 1885 (Mollusca: Soleolifera)

\section{Cristiane L.G.F. Mendonça ${ }^{1}$, Omar S. Carvalho ${ }^{1}$ and Henrique L. Lenzi ${ }^{2}$}

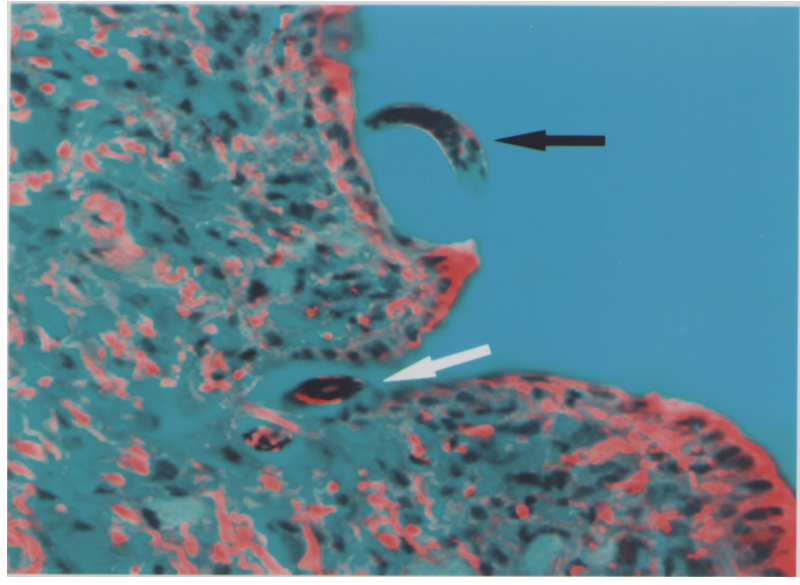

A

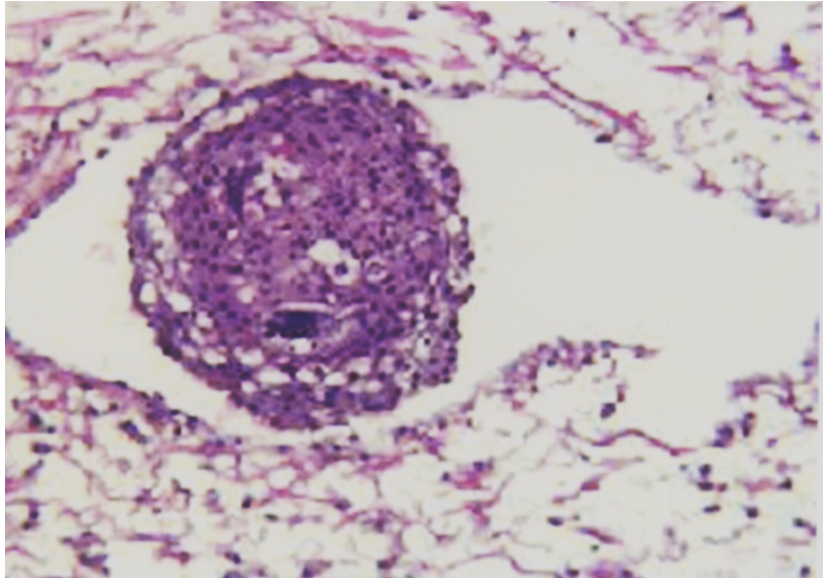

B

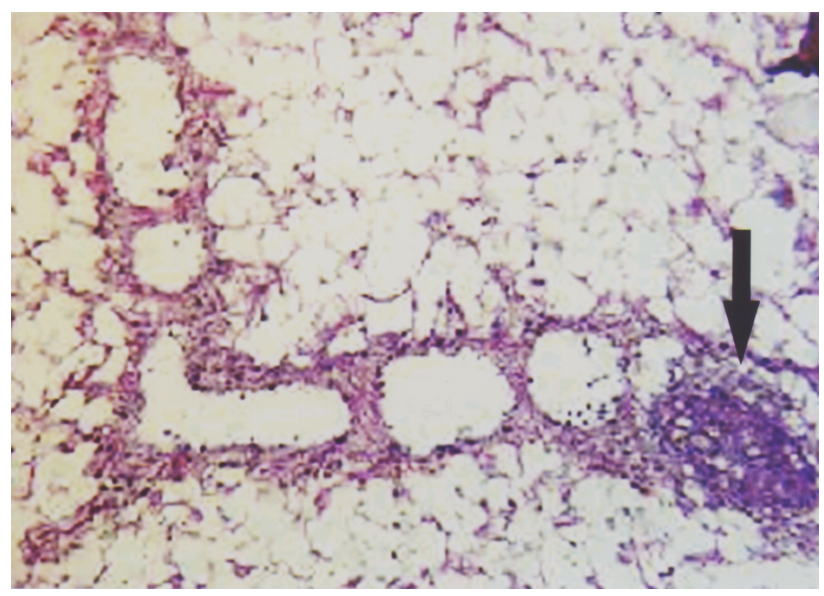

C

1. Laboratório de Helmintoses Intestinais do Centro de Pesquisas René Rachou da Fundação Oswaldo Cruz, Belo Horizonte, MG, Brasil. 2. Departamento de Patologia do Instituto Oswaldo Cruz/FIOCRUZ, Rio de Janeiro, RJ, Brasil.

Apoio financeiro: PAPES 2/FIOCRUZ.

Endereço para correspondência:Dr. Omar S. Carvalho. Centro de Pesquisas René Rachou/FIOCRUZ. Av. Augusto de Lima 1715, Barro Preto, $30190-002$ Belo Horizonte, MG.

Recebido para publicação em 02/1/2002. 
Angiostrongylus costaricensis, the etiological agent of abdominal angiostrongylosis, has sylvatic rodents as its definitive host the and terrestrial snails (slugs) as the intermediate host. Experimental infection of Sarasinula marginata with $A$. costaricensis occurs in two ways. Ingested L1 larvae, having passed through the digestive epithelium become located in different organs. Larvae reach the fibromuscular layer, their final habitat, crossing the kidneys and rectum or/and by vascular emboli. Only the larvae that reach the fibromuscular layer by emboli contribute to the parasite cycle through $\mathrm{L}_{3}$ elimination. L1 larvae also penetrate the skin preferably through excretory ducts of mucous cells, reaching the fibromuscular layer (Figure $A$ : larvae $-L_{1}$ - near the tegumental epithelium - black arrow - and inside excretory ducts of mucous glands - white arrow; time of infection: 30 min; HE100X). Pre-granulomatous reaction, characterized by gradual concentration of amebocytes around larvae, culminates in well-organized granuloma, 4 days after infection, consisting of a compact collection of amebocytes (Figure B: perilarval granuloma $-L_{2}$ presenting two well-defined layers: the inner part bearing epithelioid amebocytes, and the other, which is thinner, forming a pseudo-capsule constituted by fibroblast-like cells; time of infection: 5 days; HE 200X). After 21 days of infection, most of the larvae are found in the vessels surrounded by pre-granulomatous reactions, free granuloma (emboli) or attached to vascular walls (Figure C: granuloma - arrow - adhered to the wall of one of the chambers of a meta-artery, with a diffuse thick wall; time of infection: 30 days; $H E$ 200X). Elimination of $L_{3}$ seems to depend on intravascular granulomas near ducts. $S$. marginata infection by $A$. costaricensis induces systemic mobilization of amebocytes (hemocytosis) and a perilarval granulomatous reaction, with occasional transformation of amebocytes into epithelioid cells. The latter emphasizes the concept that the granuloma is a phenomenon intrinsically linked with macrophages, phylogenetically old and independent of the presence of B and T lymphocytes.
O Angiostrongylus costaricensis, agente etiológico da angioestrongilíase abdominal, tem como hospedeiros definitivos roedores silvestres e como hospedeiros intermediários moluscos terrestres (lesmas). A infecção experimental de Sarasinula marginata por Angiostrongylus costaricensis ocorre, simultaneamente, por duas vias. Pela via oral, as larvas $\mathrm{L}$, ingeridas, após ultrapassarem o epitelio do tubo digestivo, localizam-se em diferentes órgãos. As larvas acessam a camada fibromuscular, seu habitat final, por duas vias: (1) através do rim e do reto e (2) por embolização vascular. Somente as larvas que atingem a camada fibromuscular, por embolização, contribuem para a manutenção do ciclo do parasita, via eliminação de $L_{3}$. Na via cutânea, as $L_{1}$ penetram preferencialmente através de ductos excretores de células mucosas, acessando, imediatamente, a camada fibromuscular (Figura A: larva $L_{1}$ perto do epitelio tegumentar - seta preta - e dentro de duto excretor de glândula mucosa - seta branca; tempo de infecção: 30 minutos). A reação pré-granulomatosa, caracterizada pela concentração gradativa de amebócitos em torno das larvas, culmina 4 dias após a infecção em granulomas, constituídos por uma coleção compacta e organizada de amebócitos (Figura B: granuloma perilarvar - $L_{2}$ - apresentando duas camadas bem definidas: a interna, formada por células epitelióides e a externa mais fina, formando uma pseudo-cápsula constituída por células tipo fibroblasto). Decorridos 21 dias da infecção, a maioria das larvas localiza-se no intravascular, provocando reações prégranulomatosas, granulomas livres (tipo êmbolos) ou fixos, aderido à parede vascular (Figura C: granuloma - seta aderido à parede de uma das câmaras de uma metaarteríola, a qual mostra espessamento difuso de sua parede). A eliminação das larvas $L_{3}$ parece depender de granulomas intravasculares justa-ductais. A infecção de $S$. marginata por A. costaricensis induz mobilização sistêmica de amebócitos (hemocitose) e reação granulomatosa perilarvar, com transformação eventual de amebócitos em células epitelióides, enfatizando o conceito de que o granuloma é um fenômeno intrinsecamente macrofágico, filogeneticamente antigo e que prescinde da presença de linfócitos B e T.

\section{REFERÊNCIAS BIBLIOGRÁFICAS}

1. Mendonça CLG. Angiostrongylus costaricensis Morera \& Céspedes 1971 no hospedeiro intermediário Sarasinula marginata Semper, 1885 (Mollusca: Soleolifera): vias de infecção, migração e eliminação larvar. Dissertação de Mestrado, Fundação Oswaldo Cruz, Rio de Janeiro, 1999.
2. Morera P, Céspedes R. Angiostrongilosis abdominal. Una nueva parasitosis humana. Acta Medica de Costa Rica 14:159-173, 1971.

3. Morera P. Investigacion del huesped definitivo de Angiostrongylus costaricensis (Morera y Céspedes, 1971). Boletin Chileno de Parasitologia 25: 133-134, 1971. 